\title{
PENGARUH PENAMBAHAN CMC (Carboxy Methyl Cellulose) TERHADAP KARAKTERISTIK FISIK YOGHURT PROBIOTIK POTONGAN BUAH NAGA MERAH
}

\author{
Effect of Addition of CMC (Carboxy Methyl Cellulose) to Physical \\ Characteristics of Yogurt Probiotics of Red Dragon Fruit Pieces
}

\author{
Evi Luthfiana Ningsih ${ }^{1)}$, Indira Lanti Kayaputri ${ }^{2)}$ dan Imas Siti Setiasih ${ }^{2)}$ \\ 1) Mahasiswa Program Studi Teknologi Pangan Fakultas Teknologi Industri Pertanian \\ Universitas Padjadjaran, Jalan Raya Bandung - Sumedang Km21, Jatinangor, Bandung, Indonesia 40600 \\ 2) Dosen Program Studi Teknologi Pangan Fakultas Teknologi Industri Pertanian \\ Universitas Padjadjaran, Jalan Raya Bandung - Sumedang Km21, Jatinangor, Bandung, Indonesia 40600 \\ Email: evi.luthfiana23@gmail.com cc:indira.lanti@unpad.ac.id
}

Diterima 9 November 2018 ; diterima pasca revisi 27 Maret 2019

Layak diterbitkan 1 April 2019

\begin{abstract}
Probiotic yoghurt with sliced dragon fruit is an innovative food product with specific purpose. A direct addition of the fruit into yoghurt could damage substances in the yoghurt, such as the occurrence of sineresys. A stabilizer, such as Carboxyl Methyl Cellulose (CMC), therefore should be added to prevent the damage. However, stabilizer addition could also affect the yoghurt characteristics, such as yoghurt viscosity and total solids. The purpose of this research was to understand the effect of CMC addition towards the probiotic yoghurt stability, viscosity, and total solids after added with sliced dragon fruit. This research used an experimental method with Randomized Block Design, consisted of 4 treatments done in triplicate. The treatments were consisted of $0.2 \%, 0.4 \%, 0.6 \%$, and $0.8 \%(\mathrm{w} / \mathrm{v})$ of CMC addition. The two parameters examined in this research were yoghurt viscosity and total solids. The result showed that CMC addition at 0.2\%, 0.4\%, 0.6\%, and 0.8\% (w/v) had no significant effect on the yoghurt total solid and viscosity. The best addition was shown at $0.2 \%(w / v)$ CMC addition, which showed $99.99 \%$ yoghurt stability, viscosity at 1087 mPas, and total dissolved solids at $10.25^{\circ}$ brix.
\end{abstract}

Keywords: CMC; stability; total solids; viscosity; yoghurt 


\section{ABSTRAK}

Yoghurt probiotik potongan buah naga merupakan salah satu inovasi produk pangan dengan tujuan khusus. Penambahan buah-buahan secara langsung kedalam yoghurt mudah mengalami kerusakan seperti sineresis, untuk mencegah hal tersebut maka dilakukan penambahan bahan penstabil yaitu CMC (Carboxy Methyl Cellulose). Penambahan bahan penstabil dapat mempengaruhi karakteristik fisik yoghurt seperti viskositas dan total padatan terlarut. Tujuan penelitian untuk mengetahui pengaruh penambahan CMC terhadap stabilitas, viskositas, dan total padatan terlarut. yoghurt probiotik potongan buah naga merah. Metode penelitian yang digunakan adalah metode eksperimental menggunakan Rancangan Acak Kelompok yang terdiri dari 4 perlakuan dengan 3 kali ulangan, perlakuan yang dilakukan yaitu 0,2\%,0,4\%,0,6\%, dan 0,8\% (b/v). parameter yang diujikan yaitu total padatan terlarut dan viskositas. Hasil penelitian menunjukkan bahwa penambahan CMC $0,2 \%, 0,4 \%, 0,6 \%$, dan 0,8\% (b/v) memberikan pengaruh tidak berbeda nyata terhadap total padatan terlarut dan viskositas. Serta perlakuan terbaik dihasilkan oleh konsentrasi CMC 0,2\% (b/v) dengan karakteristik stabilitas 99,99\%, viskositas 1087 mPas, dan Total padatan terlarut $10,25^{\circ}$ brix.

Kata Kunci: CMC; stabilitas; total padatan terlarut; viskositas; yoghurt

\section{PENDAHULUAN}

Produksi susu perusahaan sapi perah di Indonesia meningkat setiap tahunnya. Menurut Badan Pusat Statistik (2016) terjadi peningkatan hasil produksi susu dari sapi perah dari tahun 2012 - 2015, yaitu dari 30.540.000 L menjadi 70.758.000 L. Data tersebut menunjukkan peningkatan produksi susu yang cukup signifikan. Peningkatan hasil produksi susu diiringi dengan variasi olahan susu, salah satunya adalah yoghurt probiotik. Yoghurt probiotik menggunakan starter bakteri asam laktat Lactobacilus bulgaricus dan Streptococcus thermophyllus serta bakteri probiotik Lactobacillus acidophilus atau Bifidobacterium. Peningkatan kualitas yoghurt dilakukan salah satunya dengan penambahan buah-buahan. Penambahan buah naga pada yoghurt karena memiliki kandungan antioksidan dan antosianin. Mahattanatawee dkk. (2006) buah naga merah memiliki aktivitas antioksidan yang

\footnotetext{
*Corresponding author:

Evi Luthfiana Ningsih

Email : evi.luthfiana23@gmail.com

Mahasiswa Program Studi Teknologi Pangan

Fakultas Teknologi Industri Pertanian Universitas

Padjadjaran, Jalan Raya Bandung - Sumedang

Km21, Jatinangor, Bandung, Indonesia 40600.
}

diukur dengan metode DPPH sebesar $134,1 \pm 30,1 \mu \mathrm{g} \mathrm{GA} / \mathrm{g}$ puree. Yoghurt yang dihasilkan mengandung kaya antioksidan. Selain itu, buah naga juga dapat memperbaiki warna yoghurt yang dihasilkan karena mengandung antosianin sebanyak 8,8 $\mathrm{mg} / 100 \mathrm{~g}$ dari daging buahnya (Sudarmi dan Subagyo, 2015).

$$
\text { Yoghurt mudah mengalami }
$$

kerusakan salah satunya sineresis. Hasil penelitian Muhazir (2017) menyatakan bahwa pada yoghurt berisi buah naga merah dari UKM M'Yoo terjadi pemisahan antara padatan dan cairan bila disimpan pada suhu $5^{\circ} \mathrm{C}$ selama 6 hari. Pemisahan akan semakin tinggi bila disimpan pada suhu $25^{\circ} \mathrm{C}$ dan $45^{\circ} \mathrm{C}$ selama $25 \mathrm{jam}$. Hal ini disebabkan aktivitas bakteri asam laktat lebih cepat, apabila suhu penyimpanan yang digunakan semakin tinggi. Pemisahan antara padatan dan cairan disebut sineresis. Terjadinya sineresis berpengaruh terhadap penerimaan konsumen. Salah satu cara untuk mencegah terjadinya sineresis, yaitu

How to cite:

Ninsih, E. L., Kayaputri, I. L., \& Setiasih, I., S. (2019). Pengaruh Penambahan CMC (Carboxy Methyl Cellulose) Terhadap Karakteristik Fisik Yoghurt Probiotik Potongan Buah Naga Merah. Jurnal Ilmu dan Teknologi Hasil Ternak, 14 (1), 60-69 
dilakukan penambahan bahan penstabil pada yoghurt. Fungsi dari bahan penstabil adalah untuk mengikat air dan meningkatkan viskositas yoghurt (Tamime and Robinson, 2000).

Bahan penstabil yang dapat ditambahkan pada produk yoghurt, yaitu gelatin, carboxy methyl cellulose (CMC), gum arab, pektin, alginat, dan karagenan (Andiç et al., 2013). Bahan penstabil yang ditambahkan pada penelitian ini adalah CMC. Penstabil CMC cocok digunakan pada yoghurt karena tidak berbau, meningkatkan viskositas, larut dalam air dingin ataupun air panas bahkan lebih larut dalam campuran etanol atau air dan alkohol 50\%, dan dapat stabil pada pH 3-7 (Imeson, 2010), serta di dalam yoghurt terjadi interaksi antara CMC dan kasein untuk mencegah sineresis dan meningkatkan viskositas pada $\mathrm{pH}$ yang renda. Bukti bahwa CMC dapat mengurangi sineresis pada yoghurt, hasil penelitian Andiç et al., (2013) menyatakan bahwa yoghurt yang ditambah CMC sebanyak 0,5\% menghasilkan kestabilan $93 \%$ pada suhu penyimpanan $4 \pm 1^{\circ} \mathrm{C}$ selama 15 hari.

Penambahan CMC pada yoghurt akan mempengaruhi karakteristik fisik seperti viskositas dan total padatan terlarut, maka dari itu akan dilakukan pengujian viskositas dan total padatan terlarut pada yoghurt probiotik buah naga yang ditambah CMC. Adapun tujuan penelitian ini adalah untuk mengetahui pengaruh penambahan CMC terhadap viskositas dan total padatan terlarut pada yoghurt probiotik potongan buah naga merah.

\section{MATERI DAN METODE}

Waktu penelitian dilaksanakan pada bulan April - Juli 2018. Tempat penelitian dilaksanakan di Laboraturium Uji, Laboraturium Teknologi Pangan, Laboraturium Keteknikan Pengolahan Pangan Departemen Teknologi Industri Pangan Fakultas Teknologi Industri Pertanian. Universitas padjadjaran. Metode penelitian yang digunakan adalah metode eksperimental, menggunakan Rancangan Acak Kelompok (RAK) yang terdiri dari 4 perlakuan dengan 3 kali ulangan. Pada penelitian ini dilakukan 4 perlakuan yaitu: $0,2 \%, \quad 0,4 \%, \quad 0,6 \%$, dan $0,8 \% \quad(\mathrm{~b} / \mathrm{v})$, kemudian dilanjutkan dengan pengujian viskositas dan total padatan. Peralatan yang digunakan adalah panci, kompor, termometer, pisau, sendok, corong, mixer, inkubator $40^{\circ} \mathrm{C}$, botol $360 \mathrm{ml}$, inkubator, botol, sentrifugasi, dan freezer, neraca analitik, refraktometer, dan viscometer digital. Bahan-bahan yang digunakan adalah susu sapi segar, buah naga, starter freeze dried "komersial", bahan penstabil CMC, air, dan gula.

\section{Pembuatan Mother Culture}

Susu disiapkan untuk dilakukan pasteurisasi, pasteurisasi dilakukan selama 30 menit pada suhu $80 \pm 2^{\circ} \mathrm{C}$ untuk mematikan mikroorganisme patogen dan pembusuk serta menonaktifkan enzim, lalu penurunan suhu sampai $40 \pm 1^{\circ} \mathrm{C}$ bertujuan untuk pada saat starter diinokulasikan suhunya mencapai suhu optimum untuk tumbuh, selanjutnya inokulasi starter adalah proses memasukkan mikroorganisme dari starter freeze dried "komersial" kedalam susu sebesar $5 \mathrm{~g}$ (b/v), kemudian dilakukan inkubasi pada suhu $40 \pm 1^{\circ} \mathrm{C}$, dan selama 6 jam bertujuan untuk proses fermentasi yang dilakukan oleh bakteri. Setelah proses inkubasi dilakukan kemudian disimpan pada suhu $5 \pm 2{ }^{\circ} \mathrm{C}$

\section{Pembuatan Campuran Potongan Buah Naga dan Larutan Gula}

Proses pembuatan ini dilakukan dengan steril agar mengurangi kontaminasi. Pertama, buah naga merah dilakukan pencucian, pengupasan dilakukan untuk memisahkan daging buah dengan kulitnya, lalu dilakukan pemotongan dadu $1 \mathrm{~cm} \mathrm{x}$ $1 \mathrm{~cm}$, kemudian potongan buah naga ditambahkan larutan gula 50\% dengan perbandingan $3: 2$, aduk agar tercampur. 


\section{Pembuatan Yoghurt Probiotik Berisi Potongan Buah Naga dengan Penambahan CMC}

Pertama-tama susu sapi disiapkan untuk dilakukan pasteurisasi, dipasteurisasi pada suhu $80 \pm 2^{\circ} \mathrm{C}$ selama 30 menit diiringi penambahan $\mathrm{CMC}$ sesuai dengan perlakuan yaitu $0,2 \%, 0,4 \%, 0,6 \%$, dan $0,8 \% \quad(\mathrm{~b} / \mathrm{v}), \quad$ selanjutnya dilakukan penurunan suhu sampai $40 \pm 1^{\circ} \mathrm{C}$ dan penambahan starter freeze dried (Mother culture) $3 \%(\mathrm{v} / \mathrm{v})$, lalu inkubasi pada suhu $40 \pm 1^{\circ} \mathrm{C}$ selama 6 jam, setelah inkubasi ditambahkan potongan buah naga dan larutan gula sebanyak 10\% (b/v). Setelah itu, masukan kedalam jar, dan simpan pada suhu $5 \pm 2^{\circ} \mathrm{C}$ selama 12 jam.

\section{Stabilitas (Modifikasi Panesar dan Shinde, 2011) \\ Pengujian dilakukan selama 15 hari pada suhu penyimpanan $5^{\circ} \mathrm{C}$ dengan pengamatan setiap 3 hari. Sampel diambil $15 \mathrm{~g}$ untuk pengujian, kemudian disentrifugasi kecepatan $500 \mathrm{rpm}$ selama 5 menit, dipisahkan lalu ukur supernatan yang dihasilkan. Persen kestabilan dihitung dengan rumus:}

stabilitas $\%=100 \%-\left(\frac{\text { berat supernatan }}{\text { berat sampel }} \times 100 \%\right)$

\section{Viskositas (Espinar, 2010)}

Mula-mula sampel dimasukkan kedalam beaker glass, kemudian pemilihan spindel disesuaikan dengan sampel yang akan di uji, semakin kental sampel semakin besar nomor spindel yang digunakan, selanjutnya atur parameter pada display (nomor spindel dan kecepatan), lalu turunkan spindel hingga batas tercelup ke dalam cairan sampel yang akan diukur viskositasnya.

Nyalakan dengan cara menekan tombol "start" yang ada di viskometer. Tunggu sampai data pengukuran stabil (pengukuran optimal pada pembacaan skala $15 \%-90 \%)$. Bacalah dan catat angka yang ditujukan pada layar.

\section{Total Padatan Terlarut}

Refraktometer dibersihkan bagian kacanya dengan menggunakan air dan dikeringkan dengan tisu hingga kering, kemudian pengukuran dilakukan dengan mengambil 1-2 tetes sampel diletakkan pada tempat sampel berbentuk kaca kemudian ditutup. Setelah itu, pengukuran dilakukan dengan melihat wilayah yang bercahaya dan akan melihat jumlah padatan terlarut yang dinyatakan dalam satuan derajat brix.

\section{HASIL DAN PEMBAHASAN}

\section{Stabilitas}

Stabilitas yoghurt adalah seratus persen dikurangi persentase sineresis (Panesar and Shinde, 2011). Berdasarkan hasil uji statistik, pengujian stabilitas yoghurt dilakukan pada 2 waktu penyimpanan menunjukkan bahwa penambahan berbagai konsentrasi CMC memiliki pengaruh berbeda nyata pada suhu penyimpanan $5 \pm 2^{\circ} \mathrm{C}$ selama $12 \mathrm{jam}$, dan tidak berbeda nyata pada suhu penyimpanan $5 \pm 2^{\circ} \mathrm{C}$ saat hari ke-15. Tabel 1 menunjukkan stabilitas yoghurt probiotik berisi potongan buah naga merah pada suhu dan waktu penyimpanan.

Tabel 1 menunjukkan bahwa stabilitas yoghurt pada suhu penyimpanan 5 $\pm 2^{\circ} \mathrm{C}$ selama 12 jam berbeda nyata untuk penambahan CMC $0,2 \%$ sedangkan pada penambahan CMC 0,4\%, 0,6\%, dan 0,8\% tidak berbeda nyata. Hal ini diduga karena penambahan CMC 0,2\% membentuk ikatan $\mathrm{CMC}$ dan kasein lebih sedikit dibandingkan pada penambahan CMC yang lain sehingga dapat memengaruhi sineresis dan menurunkan stabilitas yoghurt. Sumardikan (2007) menyatakan semakin tinggi konsentrasi CMC $0,5 \%$ yang digunakan maka sineresis yoghurt akan semakin rendah dibandingkan yoghurt yang ditambah CMC 0,4\%. Stabilitas yoghurt pada suhu penyimpanan $5 \pm 2^{\circ} \mathrm{C}$ saat hari ke - 15 menunjukkan hasil yang tidak berbeda nyata pada berbagai perlakuan. 
Tabel 1. Pengaruh Konsentrasi CMC terhadap Stabilitas Yoghurt Probiotik Berisi Potongan Buah Naga Merah

\begin{tabular}{ccc}
\hline & \multicolumn{2}{c}{ Stabilitas Yoghurt (\%) } \\
Perlakuan (b/v) & 12 jam Suhu & Hari Ke -15 Suhu \\
& $5 \pm 2^{\circ} \mathrm{C}$ & $5 \pm 2^{\circ} \mathrm{C}$ \\
\hline Penambahan CMC 0,2\% & $99,99 \pm 0,002^{\mathrm{b}}$ & $99,99 \pm 0,003^{\mathrm{a}}$ \\
Penambahan CMC 0,4\% & $100 \pm 0,00^{\mathrm{a}}$ & $99,98 \pm 0,02^{\mathrm{a}}$ \\
Penambahan CMC 0,6\% & $100 \pm 0,00^{\mathrm{a}}$ & $99,98 \pm 0,02^{\mathrm{a}}$ \\
Penambahan CMC 0,8\% & $100 \pm 0,00^{\mathrm{a}}$ & $99,98 \pm 0,02^{\mathrm{a}}$ \\
\hline
\end{tabular}

Keterangan: Rata-rata perlakuan yang ditandai dengan huruf yang sama tidak berbeda nyata pada taraf 5\% berdasarkan uji Duncan (dibaca kearah vertikal)

Hal ini karena penambahan CMC $0,2 \%$ sampai $0,8 \%$ tidak memberikan efek berbeda nyata terhadap stabilitas yoghurt probiotik selama masa penyimpanan. Stabilitas dipengaruhi oleh total padatan dari yoghurt. Connolly (2013) menjelaskan bahwa kandungan total padatan, kandungan protein, dan jumlah bahan penstabil yang ditambahkan dapat memainkan peranan penting dalam penentuan stabilitas yoghurt. Hal ini telah sesuai karena total padatan yoghurt yang ditambah CMC tidak berbeda nyata.

Stabilitas yoghurt menurun pada suhu penyimpanan $5 \pm 1^{\circ} \mathrm{C}$ selama 12 jam sampai hari ke - 15. Lama penyimpanan pada suhu $4-5^{\circ} \mathrm{C}$ dapat menurunkan kestabilan pada yoghurt, hal ini sesuai dengan penelitian Andiç et al., (2013) pada pembuatan yoghurt dengan pengaruh bahan penstabil CMC dilakukan pengamtan kestabilan dengan lama penyimpanan 15 hari dengan suhu $4 \pm 1^{\circ} \mathrm{C}$, nilai stabilitas yang dihasilkan sebesar 93\%. Penurunan stabilitas ini digambarkan dengan munculnya cairan diatas permukaan yoghurt, sehingga menyebabkan terjadinya sineresis atau pemisahan padatan dan cairannya pada yoghurt. Pengujian stabilitas yoghurt diamati setiap 3 hari sekali selama 15 hari penyimpanan yang disajikan dalam bentuk grafik. Perubahan stabilitas yoghurt probiotik berisi potongan buah naga merah pada suhu penyimpanan 5 $\pm 2^{\circ} \mathrm{C}$ selama 15 hari disajikan pada Gambar 1 .

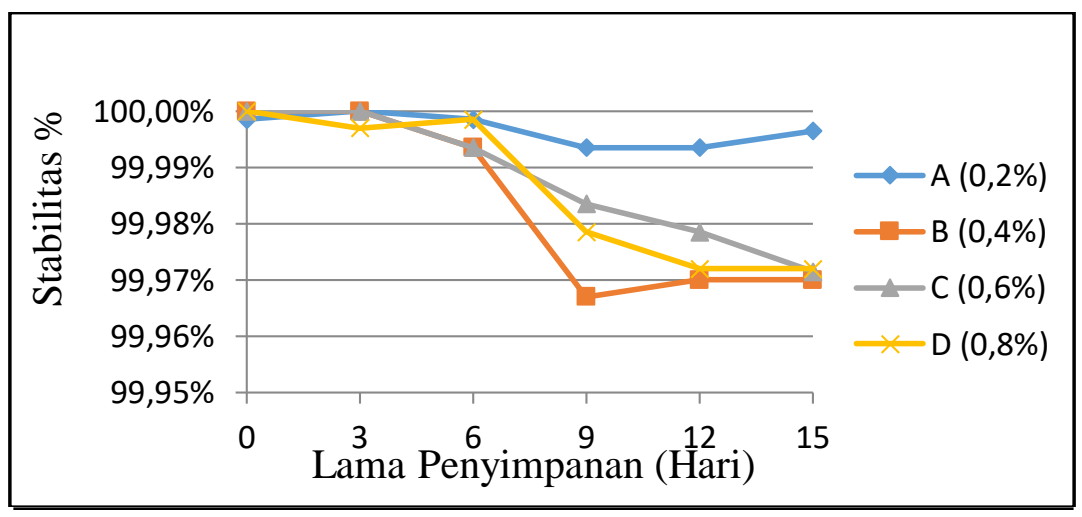

Gambar 1. Grafik Perubahan Stabilitas Yoghurt Probiotik Berisi Potongan Buah Naga Merah pada Suhu Penyimpanan $5 \pm 2^{\circ} \mathrm{C}$ Selama 15 Hari

Gambar 1 menunjukkan bahwa stabilitas yoghurt probiotik berisi potongan buah naga merah semakin menurun pada suhu penyimpanan $5 \pm 2^{\circ} \mathrm{C}$ selama 15 hari. Perubahan stabilitas yoghurt pada hari pertama sampai hari ke enam masih mempertahankan stabilitasnya. Namun, setelah hari ke enam terjadi penurunan stabilitas secara tajam. Menurut Manab (2008) sineresis yoghurt selama masa 
penyimpanan sampai hari ke enam mengalami sedikit penurunan dan setelah penyimpanan hari ke sembilan dan seterusnya cenderung penurunan tekstur. Penurunan stabilitas yoghurt juga dipengaruhi lama penyimpanan, semakin lama penyimpanan menghasilkan peningkatan total asam laktat. Menurut Kalab (2005) pada lingkungan yang asam mengakibatkan ikatan hidrogen antara molekul air dan molekul protein melemah yang menyebabkan pori-pori diantara molekul kasein melonggar sehingga molekul air dapat terlepas yang mulanya terikat protein, melepasnya molekul air mengakibatkan perubahan tekstur yang dapat memengaruhi kestabilan pada yoghurt. Selain pengaruh asam laktat dan lama penyimpanan pada yoghurt, menurut Sakinah (2010) terdapat faktor lain yang memengaruhi stabilitas yoghurt, yaitu tingginya suhu penyimpanan, rendahnya total padatan dalam susu, dan gangguan mekanis selama penyimpanan atau selama tranportasi.

Stabilitas yoghurt yang ditambah CMC $0,2 \%$ cenderung lebih stabil dibanding penambahan CMC yang semakin banyak. Penambahan bahan penstabil yang semakin banyak dapat mengikat protein yang lebih kuat, namun dapat merusak struktur jaringan secara parsial (keseluruhan) sehingga dapat menurunkan stabilitas. Penambahan bahan penstabil yang tinggi dapat membungkus misel kasein secara keseluruhan, sehingga menyebabkan ketertarikan antara misel kasein menurun sehingga dapat menyebabkan sineresis. (Andic et al., 2013). Penambahan CMC 0,2\% merupakan jumlah yang tepat untuk mempertahankan stabilitas pada yoghurt probiotik berisi buah naga, hal ini didukung oleh Andic et al., (2013) yoghurt pada penambahan CMC $0,25 \%$ lebih stabil dibanding dengan penambahan $\mathrm{CMC} 0,5 \%$ pada suhu $4^{\circ} \mathrm{C}$. Secara keseluruhan stabilitas yoghurt pada suhu penyimpanan $5 \pm 2{ }^{\circ} \mathrm{C}$ selama 15 hari dapat mempertahankan stabilitas tetap pada 99\%. Hal ini dapat dinyatakan bahwa CMC mampu mempertahankan stabilitas yoghurt dalam mencegah sineresis. Siskawardani dkk (2013) menyatakan mekanisme kerja CMC sebagai bahan penstabil berhubungan erat pada kemampuannya dalam mengikat air, sehingga meningkatkan stabilitas dan viskositas larutan.

\section{Viskositas}

Viskositas diukur dengan menggunakan alat viskometer digital. Hasil uji statistik menunjukkan bahwa perlakuan penambahan CMC tidak berbeda nyata terhadap viskositas yoghurt probiotik potongan buah naga merah pada suhu penyimpanan $5 \pm 2^{\circ} \mathrm{C}$ selama $12 \mathrm{jam}$. Tabel 1 menunjukkan viskositas yoghurt probiotik berisi potongan buah naga merah.

Tabel 2. Pengaruh Penambahan CMC Terhadap Viskositas Yoghurt Probiotik Potongan Buah Naga Merah

\begin{tabular}{cc}
\hline Perlakuan (b/v) & Viskositas (mPas) \\
\hline Penambahan CMC 0,2\% & $1087 \pm 424,54^{\mathrm{a}}$ \\
Penambahan CMC 0,4\% & $1093 \pm 380,70^{\mathrm{a}}$ \\
Penambahan CMC 0,6\% & $1170 \pm 210,71^{\mathrm{a}}$ \\
Penambahan CMC 0,8\% & $1300 \pm 327,41^{\mathrm{a}}$ \\
\hline
\end{tabular}

Keterangan: Rata-rata perlakuan yang ditandai dengan huruf yang sama tidak berbeda nyata pada taraf $5 \%$ berdasarkan uji duncan

Tabel 2 menunjukkan bahwa viskositas yoghurt probiotik berisi potongan buah naga merah tidak berbeda nyata untuk setiap perlakuan penambahan CMC, karena penambahan CMC 0,2\% sampai $0,8 \%$ tidak memberikan efek berbeda terhadap viskositas yoghurt probiotik. Penambahan CMC terhadap viskositas tidak berbeda nyata sama seperti total padatan. Mahdian and Tehrani (2007) 
bahwa perbedaan tingkat kekentalan yoghurt disebabkan oleh total padatan dan juga perbedaan nilai $\mathrm{pH}$ yang terdapat pada masing-masing produk, karena keduanya berperan dalam penggumpalkan kasein dan protein yang membentuk viskositas dan tekstur pada yoghurt. Manab (2008) menyatakan viskositas susu dan yogurt dipengaruhi oleh $\mathrm{pH}$, kadar protein, total padatan, jenis kultur strain, dan waktu inkubasi.

Yoghurt probiotik yang ditambah CMC menghasilkan viskositas sebesar 1087 - 1300 mPas, dimana rentang tersebut semakin naik beriring dengan penambahan konsentrasi CMC kedalam yoghurt. Hal ini sesuai dengan penelitian yang dilakukan oleh Cakrawati dan Kusumah (2016) mengenai pengaruh penambahan CMC terhadap yoghurt tepung gembili, dengan hasil menunjukkan peningkatan viskositas dari yoghurt tepung gembili seiring dengan penambahan $\mathrm{CMC}$ dengan konsentrasi $0,2 \%, 0,4 \%, 0,6 \%$ dan $0,8 \%$. Peningkatan viskositas terjadi karena adanya interaksi antara kasein dan CMC.

Kasein adalah protein yang mendominasi di dalam susu, dimana dalam kasein mengandung asam amino. Wustenberg (2015) menyatakan asam amino mempunyai gugus elektron (- NH2) menerima proton dari oxonium yaitu oksigen yang mempunyai 3 proton (H3O+) menghasilkan asam amino mempunyai gugus positif $\left(-\mathrm{NH}_{3}{ }^{+}\right)$. Antara ikatan kation protein $\left(-\mathrm{NH}_{3}{ }^{+}\right)$dan anion CMC (-COO-) terjadi gaya elektrostatik sehingga menghasilkan gaya tarik menarik. Adanya gaya tarik menarik antara protein dan CMC mampu meningkatkan viskositas yoghurt. Berdasarkan proses pembuatannya yoghurt probiotik berisi potongan buah naga termasuk dalam kategori stirred yoghurt karena dilakukan pengadukan setelah fermentasi. Standar viskositas stirred yoghurt yaitu $1500 \mathrm{mPas}$ (PCM, 2018), sedangkan viskositas yoghurt yang dihasilkan sebesar $1087 \mathrm{mPas}-1300$ mPas, dimana pada rentang tersebut sudah mendekati standar viskositas stirred yoghurt.

\section{Total Padatan Terlarut}

Total padatan terlarut adalah jumlah padatan terlarut yang terdapat dalam suatu produk. Pengujian total padatan terlarut dengan menggunakan refraktometer Abbe. Hasil uji statistik menunjukkan bahwa perlakuan penambahan CMC tidak berbeda nyata terhadap total padatan terlarut yoghurt probiotik berisi potongan buah naga merah pada suhu penyimpanan $5 \pm$ $2^{\circ} \mathrm{C}$ selama 12 jam. Tabel 3 menunjukkan total padatan terlarut yoghurt probiotik potongan buah naga merah.

Tabel 3 menunjukkan bahwa total padatan terlarut yoghurt probiotik berisi potongan buah naga merah tidak berbeda nyata untuk setiap perlakuan penambahan CMC. Hal ini karena penambahan CMC sebanyak $0,2 \%$ - $0,8 \%$ tidak memberikan pengaruh terhadap total padatan terlarut yoghurt probiotik. Total padatan terlarut yang dihasilkan dipengaruhi oleh viskositas. Semakin banyak penambahan stabilizer pada yoghurt maka akan membentuk tekstur dan total padatan yang meningkat (Andic et al., 2013).

Tabel 3. Pengaruh Penambahan CMC terhadap Total Padatan Yoghurt Probiotik Potongan Buah Naga Merah

\begin{tabular}{cc}
\hline Perlakuan (b/v) & Total Padatan Terlarut ( ${ }^{\circ}$ brix) \\
\hline Penambahan CMC 0,2\% & $10,25 \pm 2,41^{\mathrm{a}}$ \\
Penambahan CMC 0,4\% & $10,22 \pm 1,99^{\mathrm{a}}$ \\
Penambahan CMC 0,6\% & $10,53 \pm 1,57^{\mathrm{a}}$ \\
Penambahan CMC 0,8\% & $11 \pm 0,66^{\mathrm{a}}$ \\
\hline
\end{tabular}

Keterangan: Rata-rata perlakuan yang ditandai dengan huruf yang sama tidak berbeda nyata pada taraf $5 \%$ berdasarkan uji duncan 
Nilai total padatan terlarut yang terhitung dalam yoghurt probiotik berisi potongan buah naga merah yaitu total gula, asam laktat, dan asam-asam organik. Total gula dihasilkan dari bahan yang digunakan, yaitu susu, buah naga, dan larutan gula. Susu memiliki laktosa paling dominan, buah naga memilki fruktosa dan glukosa, dan larutan gula memiliki sukrosa.

Asam laktat dan asam-asam organik dihasilkan dari fermentasi bakteri asam laktat. Menurut Fardiaz (2003) metabolit asam laktat dan asam-asam organik tersekresikan keluar sel dan akan terakumulasi selama fermentasi. Sisa hasil total gula, asam laktat, dan asam organik yang terbentuk terhitung sebagai total padatan terlarut. Menurut Djaafar dan Rahayu (2007) menyatakan bahwa yoghurt buah menghasilkan total padatan terlarut berkisar antara 8,4 obrix - 10,5 obrix. Menurut Tamime and Robinson (2000), kualitas yogurt ditentukan oleh viskositas dan konsistensi koagulan yang kesemuanya itu ditentukan oleh keberadaan total padatan yang dikandungnya.

Semakin tinggi total padatan akan meningkatkan viskositas dan konsistensi koagulan yogurt. Nilai total padatan terlarut yoghurt probiotik berisi potongan buah naga merah berada dalam kisaran 10,22obrix - 11obrix. Total padatan yang dihasilkan telah memenuhi standar SNI 012981-2009 minimum 8,2\%.

\section{KESIMPULAN}

Penelitian ini dapat disimpulkan bahwa penambahan CMC 0,2\%, 0,4\%, $0,6 \%, 0,8 \%(\mathrm{~b} / \mathrm{v})$ dapat digunakan kedalam yoghurt probiotik potongan buah naga merah karena telah sesuai telah sesuai standard mutu yoghurt yaitu SNI 01-29812009 serta memberikan pengaruh tidak berbeda nyata terhadap viskositas dan total padatan terlarut.

\section{UCAPAN TERIMA KASIH}

Terimakasih kepada Ibu Indira Lanti S.Pt.,M.Si, atas bantuannya dalam penyusunan naskah dan dukungan dana terhadap penelitian ini, Prof. Dr. Ir. Imas Siti Setiasih .S.U atas bantuannya dalam mengarahkan penyusunan naskah ini, serta seluruh laboran dari laboraturium departemen teknologi pangan Kang Arif, Teh Veni,dan Teh Tia yang telah membantu mengarahkan penulis selama penelitian berlangsung.

\section{DAFTAR PUSTAKA}

Andic, S., Boran, G., \& Tuncturk, Y. (2013). Effects of carboxyl methyl cellulose and edible cow gelatin on physico-chemical, textural and sensory properties of yoghurt. International Journal of Agriculture and Biology (Pakistan), 15(2).

Anggraini, D., Radiati, L., \& Purwadi, P. (2016). Carboxymethyle cellulose (CMC) addition in term of taste, aroma, color, $\mathrm{pH}$, viscosity, and turbidity of apple cider honey drink. Jurnal Ilmu Dan Teknologi Hasil Ternak, 11(1), 58-67. https://doi.org/10.21776/ub.jitek.2016.011.01.7

Badan Pusat Statistik. (2016). Produksi Susu Perusahaan Sapi Perah. Jakarta: Badan Pusat Statistik.

Badan Standarisasi Nasional. (2009). Yoghurt. Jakarta: Pusat Standarisasi Departemen Perindustrian dan Perdagangan Indonesia.

Cakrawati, D., \& Kusumah, M. A. (2012). Pengaruh penambahan CMC sebagai senyawa penstabil terhadap yoghurt tepung gembili. AGROINTEK, 10(2), 77-85. 
Connolly, P. (2013). Milk Protein Concentrate in Yogurt.

Djaafar, T., \& Rahayu, S. (2007). Preferensi Konsumen Terhadap Yoghurt Buah dan Sifat Kimianya. Yogyakarta: Balai Pengkajian Teknologi.

Espinar, R. S. (2010). Rotational Models RP1 Trade RAYPA (Brookfield Method). Barcelona. Spain: Terasa Publishing.

Fardiaz, D. (2003). Hidrokoloid. Bogor: Institut Pertanian Bogor.

Imeson, A. (2010). Food Stabilisers,Thickeners and Gelling Agents. Inggris: Blackwell Publishing.

Kalab. (2005). Electron Microscopy of Food and Microorganism.

Kusbiantoro, B., Herawati, H., \& Ahza, A. B. (2005). Pengaruh jenis dan konsentrasi bahan penstabil terhadap mutu produk velva labu jepang. Jurnal Hortikultura, 15(3), 66-77. https://doi.org/10.21082/jhort.v15n3.2005.p\%p

Mahattanatawee, K., Manthey, J. A., Luzio, G., Talcott, S. T., Goodner, K., \& Baldwin, E. A. (2006). Total antioxidant activity and fiber content of select florida-grown tropical fruits. Journal of Agricultural and Food Chemistry, 54(19), 7355-7363. https://doi.org/10.1021/jf060566s

Mahdian, E., \& Tehrani, M. (2007). Evaluation the effect of milk total solids on the relationship between growth and activity of starter cultures and quality of concentrated yoghurt. American-Eurasian J. Agric. \& Environ. Sci, 2(5), 587-592.
Manab, A. (2008). Kajian sifat fisik yogurt selama penyimpanan suhu $4^{\circ} \mathrm{C}$. Jurnal Ilmu Dan Teknologi Hasil Ternak (JITEK), 3(1), 52-58.

Muhazir, F. (2017). Pendugaan Umur Simpan Yogurt Buah Naga Merah UKM M'yogurt Pada Suhu Penyimpanan yang Berbeda Menggunakan Metode Accelerated Shelf Life Testing (ASLT) Model Arrhenius (Skripsi). Bandung: Universitas Padjadjaran.

Panesar, P. S., \& Shinde, C. (2012). Effect of storage on syneresis, $\mathrm{pH}$, lactobacillus acidophilus count, bifidobacterium bifidum count of aloe vera fortified probiotic yoghurt. Current Research in Dairy Sciences, 4(1), 17-23. https://doi.org/10.3923/crds.2012.17.23

PCM. (2018). Set, Stirred, and Drinking Yoghurt.

Sakinah, N., Dwiyanti, G., \& Darsati, S. (2010). Pengaruh penambahan DHA terhadap ketahanan susu pasteurisasi. Jurnal Sains Dan Teknologi Kimia.

Siskawardani, D., Komar, N., \& Hermanto, M. (2013). Pengaruh konsentrasI NaCMC (natrium- carboxymethyle cellulose) dan lama sentrifugasi terhadap sifat fisik kimia minuman asam sari tebu (saccharum officinarum 1 ). Jurnal Bioproses Komoditas Tropis, 1(1), 54-61.

Sudarmi, S., \& Subagyo, P. (2015). Ekstraksi sederhana antosianin dari kulit buah naga (hylocereus polyrhizus) sebagai pewarna alami. International Journal of Renewable Energt Development, 12(1). 
Sumardikan. (2007). Penggunaan Carboxymethylcellulose (CMC) terhadap pH, Keasaman, Viskositas, Sineresis dan Mutu Organoleptik. Malang: Teknologi peternakan.

Tamime, A., \& Robinson, R. (2000). Yoghurt: Science and Technology (2nd ed.). New York: CRC Press.
Wustenberg, T. (2015). Cellulose and Cellulose Devirates in the Food Industry. Jerman: Wiley-VCH. 